Piotr Żurek

Akademia Techniczno-Humanistyczna

w Bielsku-Białej

pzurek@ath.bielsko.pl
Data przesłania tekstu do redakcji: 08.10.2014

Data przyjęcia tekstu do druku: 06.12.2014

\title{
Słoweński Kościół katolicki w okresie II wojny światowej i rządów marszałka Tito (1941-1980)
}

\begin{abstract}
Piotr, Słoweński Kościót katolicki w okresie II wojny światowej i rządów marszatka Tito (1941-1980) (Slovenian Catholic Church During the Second World War and the Govern of Marshal Tito [1941-1980]). "Poznańskie Studia Slawistyczne” 10. Poznań 2016. Publishing House of the Poznan Society for the Advancement of the Arts and Sciences, pp. 281-293. ISSN 2084-3011.

The history of Slovenian Catholic Church is a field, which is not well known in Poland. That is why this article aims to present one of the peculiar episode from the past of Slovenian Catholicism. The article covers the time of the Second World War and the govern of marshal Tito. During the Second World War Slovenian Catholic Church existed under the occupation of the fascist countries - Italy and The Third Reich. In this period, the main offensive power was the communists, who were fighting against invaders and often had a negative attitude towards clergy. Their attitude resulted in collaboration of Slovenian catholic hierarchs with the communists. The communists' governs established in 1945 and the consolidation of Tito's power situated the Catholic Church in a new reality, which was Yugoslavian variant of communism called "Titoism". This doctrine shaped terms of the existence of Slovenian Catholic Church until 1980 when the marshal Tito died and the Yugoslavia's breakdown began.
\end{abstract}

Keywords: Slovenia; Catholic Church; Tito; collaboration; communism; Yugoslavia

\section{Wojna}

Bezpośrednio przed wybuchem II wojny światowej słoweński Kościół katolicki cieszył się szeroką autonomią w ramach Banowiny Drawskiej terytorialno-administracyjnej jednostki składającej się z ziem Słoweńców w Królestwie Jugosławii. Terytorium Banowiny obejmowało dwie diecezje: lublańską i lawantyńską (mariborską), ordynariusze tej ostatniej byli także administratorami Prekmurja i Doliny Mežy (Ferenc 1997: 73; Dolinar 1998: 210-213). 
Od roku 1930 na czele diecezji lublańskiej stał biskup Gregorij Rožman. Trzy lata później urząd biskupa diecezji lawantyńskiej (mariborskiej) objął Ivan J. Tomažič. Między hierarchami dochodziło do sporów na tle polityczno-ideologicznym, biskup Rožman uchodził bowiem za ultrakatolika i fanatycznego wroga komunizmu (Grmič 1997: 64-66). W swoich pismach pasterskich popierał Akcję Katolicką i wskazywał wiernym, do jakich organizacji jako katolicy nie powinni należeć (Dolinar, Griesser-Pečar 1996: 206-208). Trzeba pamiętać, że kler był wówczas mocno zaangażowany w życie polityczne. Księża katoliccy, Anton Korošec i Franc Kulovec, byli kolejno liderami największej w okresie międzywojennym partii politycznej Słoweńców - Słoweńskiej Partii Ludowej (Slovenska Ljudska Stranka; SLS ${ }^{1}$ ) (Rahten 2001). Rolę swego rodzaju młodzieżowej przybudówki SLS pełniła organizacja Straż, której założycielem był związany z biskupem Rožmanem ksiądz Lambert Ehrlich. Organizacja ta miała na celu zwalczanie tendencji lewicowych wśród słoweńskiej młodzieży (Pacek 2012: 228-230). W latach 1939-1941 kierownictwo SLS opowiadało się za współpracą Jugosławii z Niemcami. Korošec nie ukrywał fascynacji Słowacją księdza Tiso (Godeša 2004: 69-75). Wiosną 1941 roku liderzy SLS prowadzili z Niemcami i Włochami rozmowy na temat utworzenia pod zwierzchnictwem Osi państwa słoweńskiego (Godeša 2011: 176-179, 224-225).

Kiedy na początku kwietnia 1941 roku wojska włoskie wkroczyły do Lublany, biskup Rožman zapewnił Emilio Grazioliego, z nadania Mussoliniego Wysokiego Komisarza okupowanych ziem, że duchowieństwo słoweńskie będzie współpracować z włoskimi faszystami. Ordynariusz powiadomił o tym wiernych w liście pasterskim zatytułowanym Ważne wydarzenia historyczne, opublikowanym 31 lipca 1941 roku na łamach organu prasowego diecezji. Pisał między innymi:

W Niedzielę Palmową, 6 kwietnia, doszło do starć między armiami Włoch i Niemiec z jednej strony a Jugosławii z drugiej. W Wielki Piątek, 11 kwietnia, wojska włoskie pokojowo zajęły część diecezji i miasto Lublanę, natomiast całą Górną Krainę i część Dolnej Krainy wzdłuż Sawy zajęły niemieckie siły zbrojne. W niedzielę 20 kwietnia (...) odwiedziłem nowo mianowanego królewskiego komisarza Emilia Grazioli. W rozmowie z ekscelencją komisarzem wyraziłem wdzięczność duchowieństwa i wiernych,

${ }^{1}$ Partia ta powstała w Lublanie w roku 1892 i początkowo działała pod nazwą Katolicka Partia Narodowa. 
że armia pokojowo zajęła prowincję, utrzymała porządek i pozostawiła ludności swobodę, zwłaszcza w życiu religijnym. Jeżeli chodzi o współpracę przedstawicieli Kościoła z nowymi władzami faszystowskich Włoch, to dla nas, katolików, miarodajne jest słowo boże, które mówi: „Każdy niech będzie poddany władzom, sprawującym rządy nad innymi. Nie ma bowiem władzy, która by nie pochodziła od Boga, a te, które są, zostały ustanowione przez Boga" (Rzym 13,1). Wychodząc z tego stanowiska, uznajemy władzę, która jest nad nami i zgodnie ze swoim sumieniem będziemy współpracować dla szlachetnej i wiecznej korzyści ludzkości, wśród której boża Opatrzność postawiła nas jako kapłanów (Rožman 1941: 1)².

Rožman w liście powiadomił wiernych także o tym, że 3 maja król Włoch, na wniosek Mussoliniego, powołał do życia Prowincję Lublańską, która wchodzi w skład Królestwa Włoch. Według biskupa w prowincji tej słoweńska ludność będzie mogła cieszyć się wolnością kulturalną i religijną. W ostatnich zdaniach listu ordynariusz lublański w poddańczy sposób gloryfikował duce, dziękując mu za utworzenie Prowincji (dosł.: „pozostawienie trzonu narodu słoweńskiego w warunkach wolności wiary i języka”; Rožman 1941: 1). Współczesny słoweński historyk France Dolinar uważa jednak, że w tym liście biskup Rožman

nie akceptuje włoskiej okupacji. Przyjął jedynie do wiadomości fakt, że okupant zajął ojczyznę, że podzielił jego diecezje, że sprawy administracyjne musi załatwiać z nimi. W tym punkcie zamierzał być lojalny w stosunku do władz i oczywiście oczekiwał od nowych władz, iż będą one lojalne wobec niego i podległych mu wiernych (Dolinar, Griesser-Pečar 1996: 249-250).

Czytając orędzie biskupa, trudno wszakże zgodzić się z tego typu interpretacją. Przede wszystkim Dolinar nie dostrzega, że Rožman używa słowa „współpraca” i - wprost przeciwnie - jakby nie zważając na podział diecezji, skupia się tylko na włoskiej okupacji. Poza tym jego wiernopoddańczy stosunek do okupanta musiał zostać dostrzeżony przez Mussoliniego, skoro na wniosek duce 4 października 1941 roku król Włoch przyznał Rožmanowi wysokie odznaczenie ${ }^{3}$. Biskup skomentował to z hipokryzją: „Mocniejszego kopniaka nie mogli mi dać”. Już po wojnie tłumaczył, że

${ }^{2}$ „Ljubljanski škofijski list”, 31 VII 1941, s. 1. Dostępny pod adresem: <www.dlib.si/ stream/URN:NBN:SI:DOC.../PDF> [tłumaczenie moje - P.Ż.].

${ }^{3}$ Ordynariusz lublański był jedynym Słoweńcem z Prowincji Lublańskiej uhonorowanym w ten sposób. 
tym odznaczeniem chciano go nakłonić do współpracy, której się opierał. Zresztą, jak wspominał, później Włosi żałowali swojej decyzji (Ferenc 1997: 77; Dolinar, Griesser-Pečar 1996: 58, 219).

W wyniku inwazji państw Osi ziemie słoweńskie zostały rozdzielone. Większa część terytorium dawnej Banowiny Drawskiej znalazła się pod okupacją niemiecką, która zajmowała znaczne terytoria diecezji lublańskiej i lawantyńskiej (mariborskiej). W roku 1941 okrojona diecezja lublańska obejmowała większą części Dolnej Krainy oraz Wewnętrzną Krainę. Diecezja lawantyńska (mariborska) funkcjonowała tylko na obszarze słoweńskiej części Styrii. Prekmurje znalazło się pod okupacją węgierską (diecezja szombathely’ska), a Dolinę Mežy (część Karyntii) włączono do Rzeszy (Ferenc 1997: 73).

Największemu terrorowi Słoweńcy byli poddani w niemieckiej strefie okupacyjnej. Podlegali tam planowemu procesowi wynarodowiania, wysiedleniom, wywózkom na roboty i do obozów (Blumenwitz 2005: 76-78; Kacin-Wohlnz 1982: 151-167). Grabiono mienie kościelne (Prinčič 2013: 83-85). W słoweńskim Kościele katolickim Niemcy dostrzegali ostoję słoweńskiej świadomości narodowej, dlatego szczególnym represjom poddawali duchownych. Tylko w 1941 roku do Niepodległego Państwa Chorwackiego (NDH) wysiedlono 284 diecezjalnych i 81 zakonnych księży. W rezultacie większość parafii nie była obsadzona. Mimo protestów biskupa Tomažiča i interwencji Gregorija Rožmana w Watykanie, Niemcy nie zmienili polityki (Grmič 1997: 66). Przez całą wojnę ordynariusz lublański bezowocnie interweniowat ${ }^{4} \mathrm{u}$ władz okupacyjnych $\mathrm{w}$ tej sprawie, co potwierdza przekonanie, że był świadom ogromu krzywd i zbrodni, jakich naziści dopuszczali się na narodzie słoweńskim (Škulj 2001: 265-288, 301-313).

Współcześnie w Słowenii nie neguje się faktu, że biskup Rožman (oraz znaczna część słoweńskiego duchowieństwa) kolaborował z faszystami, dewaluuje się tylko pojęcie kolaboracji; poza tym krach systemu komunistycznego sprzyja przedstawianiu jego działań wyłącznie przez pryzmat walki z bolszewizmem (Dolinar, Griesser-Pečar 1996). W 1941 roku komuniści słoweńscy byli jednak ugrupowaniem marginalnym i rozbitym, dopiero II wojna światowa i poparcie społeczne, uzyskane w dużej

\footnotetext{
${ }^{4}$ Kwestia „interwencji” inaczej jest rozumiana przez część badaczy słoweńskich.
} 
mierze wskutek bankructwa kolaboracyjnej polityki elit, umożliwiły im przejęcie władzy. Kontrolowany przez Komunistyczną Partię Słowenii (KPS) słoweński Front Wyzwolenia (OF) wprowadzał władzę ludową na oswobodzonych przez siebie obszarach. Podlegające Frontowi oddziały partyzantki bezwzględnie rozprawiały się z rodzimymi ,zdrajcami”, jak nazywano współpracowników faszystów. Terror KPS bywał ślepy, co powodowało, że do grona „zdrajców” włączano ludzi z szerokiej opozycji. Za takiego wroga uważany był też Kościół katolicki i tzw. „klerofaszyści”. Ale też duchowieństwo Prowincji Lublańskiej w znacznej mierze nastawione było wrogo do Frontu i, dla przeciwwagi, niemalże za obowiązek uważało kolaborację z Włochami.

Komuniści słoweńscy traktowali wojnę de facto jako rewolucję, co doprowadziło do bratobójczej walki. Dla obrony przed partyzantami już w 1941 roku zaczęły powstawać pierwsze słoweńskie Straże Wiejskie (Vaške straže). Za założyciela tej formacji uważany jest ksiądz Lambert Ehrlich (Mlakar 1999: 8-10), który opowiadał się za lojalnością w stosunku do Włoch, ponieważ, jego zdaniem, tylko to „państwo katolickie" może zapewnić Słoweńcom przetrwanie (Godeša 2011: 285-288). Gdy rozpoczęła się wojna, działania „strażników” wymierzone zostały przede wszystkim w OF. Od roku 1942 Straże Wiejskie były wyposażane i opłacane przez Włochów, a następnie przekształcone przez nich w Ochotniczą Milicję Antykomunistyczną (MVAC) (Griesser-Pečar 2004: 253).

Z chwilą kapitulacji faszystowskich Włoch (wrzesień 1943) na tereny Słowenii, okupowane dotąd przez włoskie wojsko, wkroczyła armia niemiecka. Ustanowiono rządy zależne od III Rzeszy. Komisarz Przymorza Adriatyckiego Friedrich Rainer, zgodnie z wnioskiem biskupa Rožmana, ogłosił generała Leona Rupnika „prezydentem” administracji lublańskiej (Lešnik, Tomc 1995: 180). Zmiana układu sił i zauważalny odwrót Niemiec w Europie wzbudził u lublańskiego hierarchy jeszcze większy strach przed komunizmem. Dał temu wyraz w liście pasterskim z 30 listopada 1943 roku (Rožman 1943: 89-96), zapewne dlatego popierał też utworzenie przez Niemców Słoweńskiego Legionu Domobrańskiego na bazie Ochotniczej Milicji Antykomunistycznej. W rocznicę urodzin Hitlera, 20 kwietnia 1944 roku, biskup w obecności Rupnika i lokalnych dowódców niemieckich odprawił mszę i wziął udział w uroczystej przysiędze 
słoweńskich domobranów (Prisega 1944: 2-3)5. Mimo kolaboracyjnej postawy Rožmana, sytuacja słoweńskiego duchowieństwa katolickiego nie była jednoznacznie określona. W Przymorzu duchowieństwo masowo popierało OF, a Niemcy nie mieli skrupułów, by ze swojej strefy okupacyjnej rugować księży albo deportować ich do obozów (Graovac 2000: 547).

\section{Represje}

Gdy siły nazistowskie wycofywały się z Jugosławii, 5 maja 1945 roku, biskup Rožman wyemigrował ze Słowenii. Rok później komuniści w zaocznym procesie skazali go na 18 lat więzienia. Zmarł w roku $1959 \mathrm{w}$ Cleveland (Škulj 2001: 289-300, 329-341).

Po wyjeździe Rožmana generalnym wikariuszem diecezji lublańskiej został Anton Vovk (od grudnia 1946 był biskupem pomocniczym). Reprezentacja katolickiego kleru z nowym wikariuszem na czele 11 lipca 1945 roku złożyła na ręce premiera komunistycznej Słowenii, Borisa Kidriča, akt lojalności (Ceglar 1993: 125-126). Nie poprawiło to jednak złych stosunków Kościoła katolickiego z przejmującym władzę reżimem komunistycznym. Chodziło zarówno o kwestie światopoglądowe, jak i polityczne. Nowe władze nie potrafiły wybaczyć hierarchii katolickiej, że w czasie wojny zajęła lojalistyczną postawę wobec okupanta i rodzimych kolaborantów, dlatego w kręgach komunistycznych traktowano Kościół katolicki jako „narodowego zdrajcę”. Oliwy do ognia dolał także list pasterski Konferencji Episkopatu z Zagrzebia (Pastirsko pismo o nasiljima komunističke vlasti) odczytany 30 września 1945 roku na mszach w kościołach całego kraju. W piśmie krytykowano komunistów między innymi za prześladowania i likwidację księży, konfiskatę majątków kościelnych, brak wolności druku, nieobowiązkową religię w szkołach i represjonowanie obywateli.

Posłanie rozdrażniło jugosłowiańskich przywódców, tym bardziej że zostało opublikowane w szczytowym momencie kampanii wyborczej do Skupsztyny Ustawodawczej. Nie było też tajemnicą, że spiritus movens

${ }^{5}$ Tekst przysięgi m.in. brzmiał: „będę walczył wraz z niemieckimi siłami zbrojnymi, znajdującymi się pod dowództwem wodza Wielkich Niemiec, oddziałami SS i policji przeciwko bandytom i przeciwko komunizmowi, jako i ich sojusznikom". 
ogłoszenia listu był przewodniczący Konferencji biskupów, arcybiskup Zagrzebia - Alojzy Stepinac - uważany przez komunistów za sympatyka ustaszy i współwinnego ich zbrodni (przeszło 90\% episkopatu stanowili Chorwaci). Stepinaca nie tolerowano tym bardziej, że odrzucił wystosowane przez Titę żądanie zerwania przez Kościół katolicki Jugosławii związków z Watykanem i przekształcenia się we wspólnotę narodową. W rezultacie w roku 1946 wytoczono hierarsze proces i skazano na długoletnie więzienie (Akmadža 2003: 175-176).

Oficjalnie pod listem podpisał się wikariusz diecezji lublańskiej Anton Vovk. Słoweńskie władze zażądały od niego wyjaśnień, wikariusz bronił się jednak, twierdząc, że treść listu odnosi się przede wszystkim do sytuacji w Chorwacji, nie Słowenii. W październiku 1945 roku na łamach słoweńskiej prasy ukazała się wypowiedź Borisa Kidriča na temat biskupiego posłania. Słoweński przywódca bezwzględnie skrytykował poglądy episkopatu, ale przyjął wersję, że zupełnie nie dotyczą one Słowenii. Ostrzejsze stanowisko zajęli Tito i Edvard Kardelj (Maršal Tito 1945: 5-31; Vovk 2003: 257-260; Repe 2003: 60-61). Sytuację komplikował fakt, że Watykan nie uznawał nowych, wytyczonych po II wojnie światowej granic państwowych. Odnosiło się to przede wszystkim do dawnych obszarów Włoch, które formalnie ciągle podlegały jurysdykcji biskupów włoskich. W ten sposób w granicach powojennej Słowenii znalazły się części obszarów aż trzech włoskich diecezji: Gorycji, rijeckiej i triesteńsko-koperskiej (Darovec 2001: 266-267, 271-274).

Na początku 1951 roku Amerykanie uzależnili udzielenie pożyczki Jugosławii od wypuszczenia na wolność arcybiskupa Stepinaca, władze komunistyczne uległy temu żądaniu i w pierwszych dniach grudnia opuścił on więzienie (Bekić 1988: 323-325, 328-329, 338-340). Wzmożono jednak działania przeciw Kościołowi katolickiemu i nasilono represje wobec duchowieństwa (Režek 2004: 369-374, 378). Pod wpływem kampanii antyklerykalnej w styczniu 1952 roku w miasteczku Nowe Mesto biskup Vovk został pobity i celowo podpalony, wskutek czego doszło do dotkliwych poparzeń (Vovk 2003: 214-229).

Należy przypuszczać, że duchowieństwo katolickie w Jugosławii uznało zwolnienie Stepinaca za słabość reżimu komunistycznego. We wrześniu 1952 roku Konferencja Episkopatu Jugosławii wystosowała do władz komunistycznych memorandum Non licet (Niedozwolone), w którym 
zabroniono duchowieństwu wstępowania do prorządowych organizacji chrześcijańskich. Chodziło przede wszystkim o działające na Przymorzu Towarzystwo Cyrylometodejskie. Organizacja prowadzona była przez księży-członków OF i uważana w Watykanie za zalążek Kościoła narodowego. W roku 1950 część kleru z zarządu Towarzystwa została ekskomunikowana przez papieża. Władze komunistyczne dopatrywały się w tym działaniu spisku Watykanu przeciw Jugosławii, zwłaszcza że dwaj słoweńscy biskupi, Vovk i Maksimilian Držečnik (lawantyński biskup pomocniczy), nieopatrznie zachowali notatki z posiedzenia episkopatu, do których dotarła UDB (Uprava državne bezbednosti) w trakcie rewizji. Dokumenty wskazywały, że inspiracja do wydania memorandum płynęła z Watykanu. Komuniści zradykalizowali politykę wewnętrzną, opierając się dodatkowo na przekonaniu, że Watykan aprobuje antyjugosłowiańskie działania Włoch względem Triestu.

Od początku 1952 roku władze komunistycznej Słowenii rozpoczęły ideologiczną walkę z Kościołem. Wycofano religię ze szkół, wyłączono Wydział Teologiczny z Uniwersytetu w Lublanie, zlikwidowano organy wydawnicze diecezji lublańskiej i lawantyńskiej (mariborskiej), zabroniono obchodzenia kościelnych świąt. Księża, którzy nie podporządkowali się nowym zarządzeniom, podlegali represjom. W ciągu 1952 roku w samej Słowenii odbyło się 735 spraw karnych przeciwko księżom. Najczęściej dotyczyły one nauczania religii i odbywania procesji bez zezwolenia, jak również udzielania sakramentów bez wcześniejszych regulacji państwowych. Konflikt z Kościołem sięgnął zenitu, kiedy 29 listopada 1952 roku, w ogólnopaństwowe święto Dnia Republiki, Watykan zapowiedział nominację kardynalską Stepinaca (Akmadža 2003: 184-193; Režek 2004: 376-382). Władze Jugosławii uznały to za afront. W rezultacie 17 grudnia 1952 roku ówczesny wiceminister spraw zagranicznych Jugosławii, Słoweniec Aleš Bebler, złożył na ręce nuncjusza apostolskiego w Belgradzie Silvio Oddiego notę dyplomatyczną o zerwaniu stosunków dyplomatycznych z Watykanem. Tłumaczono ten krok faktem, że Watykan popiera włoski rewanżyzm i poprzez awans Stepinaca dopuszcza się prowokacji przeciwko Jugosławii (Režek 1999: 381-383; Akmadža 2008: 27-29, 276-282).

Poprawa relacji nastąpiła dopiero dwa lata później, 5 października 1954 roku, kiedy podpisano memorandum londyńskie regulujące kwestię granicy jugosłowiańsko-włoskiej (Jeri 1961: 290-298). Ważnym następstwem 
tej umowy dla słoweńskiego Kościoła katolickiego było włączenie dawnego obszaru słoweńskiej części strefy B (Wolnego Terytorium Triestu) pod jurysdykcję biskupa Vovka (Darovec 2001: 273).

\section{Normalizacja}

Głębsze zmiany w stosunkach między komunistycznymi władzami Słowenii a Kościołem katolickim przyniósł przełom lat 50. i 60. XX wieku. Po śmierci biskupa Rožmana papież Jan XXIII mianował nowym biskupem lublańskim Antona Vovka (26 listopada 1959 roku). Nominacja ta została dobrze przyjęta przez komunistów. Boris Kocijančič, przewodniczący słoweńskiej Komisji do spraw wyznań, osobiście pogratulował biskupowi. Władze wstrzymały nagonkę medialną na Kościół. Pod koniec 1959 roku Tito przyjął delegację duchowieństwa słoweńskiego należącego do Towarzystwa Cyrylometodejskiego. W trakcie spotkania nie wykluczył możliwości wznowienia stosunków dyplomatycznych z Watykanem (R.K. 1965: 79-80).

Nowa linia polityczna motywowana była najpewniej próbą poprawy wizerunku Jugosławii na Zachodzie. Rozumiano też, że biskupi słoweńscy zasiadali w zdominowanym przez biskupów chorwackich episkopacie Jugosławii, a to z kolei włączało ich do sporu komunistów z klerem chorwackim. Nieprzypadkowo w 1960 roku, kiedy zmarł kardynał Stepinac (10 lutego), władze jugosłowiańskie rozpoczęły rozmowy ze Stolicą Apostolską o wznowieniu stosunków dyplomatycznych (Akmadža 2004: 473-475). Znakiem odwilży w relacjach państwo - Kościół było także rządowe zezwolenie Vovkowi na podróż służbową do Watykanu w lutym 1960 roku. Według źródeł kościelnych: „Przy tej okazji udał się na spotkanie z papieżem Janem XXIII. Biskup Vovk tłumaczył się przed papieżem, że nie może paść przed nim na kolana na skutek choroby: «To ja powinienem klęknąć przed tobą». Wszyscy, których spotykał, uznawali go za męczennika" (Otrin, Štrukelj 2008: 16). W roku następnym Jan XXIII podniósł diecezję lublańską do rangi archidiecezji, a Vovk otrzymał nominację arcybiskupią (Ceglar 1998: 101).

Latem 1960 roku rozpoczęły się tajne pertraktacje w celu wznowienia stosunków dyplomatycznych między Watykanem a Jugosławią. Negocjacje były żmudne i długotrwałe, rozbijały się o kwestię chorwacką 
(Akmadža 2004: 475-481), ale mimo to poprawa relacji była widoczna. Odzwierciedlało ją między innymi uczestnictwo słoweńskich biskupów, Antona Vovka, Maksimilijana Držečnika, Jožefa Pogačnika i Janeza Jenko, w obradach II soboru watykańskiego (1962-1965) (Ceglar 1997: 156-164). W marcu 1962 roku Stolica Apostolska rozpoczęła nowelizację struktur słoweńskiego Kościoła, formalnie zmieniła nazwę diecezji lawantyńskiej na lawantyńsko-mariborską, a w 1968 roku utworzyła metropolię lublańską (Benedik 1991: 247). Po śmierci arcybiskupa Vovka, wiosną 1964 roku, nowym ordynariuszem lublańskim mianowano Jožefa Pogačnika (Merlak 2002: 153).

Pontyfikat Pawła VI zdynamizował wzajemne kontakty. Papież już w dzień swojej konsekracji 21 czerwca 1963 roku za pośrednictwem Ivo Vejvody, jugosłowiańskiego ambasadora we Włoszech, przekazał Ticie ustne informacje, że będzie dążył do poprawy stosunków między Watykanem a Jugosławią (Benedik 1991: 481-485). Jako akt dobrej woli papieża odebrano dekret z 21 grudnia 1964 roku, w którym zwierzchnik Kościoła katolickiego powołał Apostolską Administraturę Słoweńskiego Przymorza, w której skład weszły słoweńskie obszary włoskich diecezji Gorycji, rijeckiej oraz triesteńsko-koperskiej. Administratorem nowej jednostki terytorialnej słoweńskiego Kościoła został mianowany Janez Jenko (Darovec 2001: 273-274).

Kwestia ostatecznego porozumienia Jugosławii ze Stolicą Apostolską została sfinalizowana 25 czerwca 1966 roku, kiedy w Belgradzie podpisano protokół będący aktem międzynarodowym regulującym stosunki Jugosławii i Watykanu. Dokument ten gwarantował Kościołowi katolickiemu swobodę pełnienia posługi duszpasterskiej, a jednocześnie na podstawie zasady rozdziału państwa od Kościoła potwierdzał prawo obywateli do swobody praktyk religijnych. Stolica Apostolska zobowiązywała się do „nieszkodzenia” państwu jugosłowiańskiemu i do stosowania sankcji wobec wszelkich przejawów angażowania się duchowieństwa w sprawy polityczne. Zainteresowane strony wyraziły także chęć akredytacji przy swoich rządach przedstawicieli dyplomatycznych (Cvrlje 1980: 315-321; Włodarczyk 1986: 499-504; Stehle 1993: 266-267). Papież Paweł VI 28 marca 1971 roku przyjął na audiencji w Watykanie Josipa Broza Titę. Była to pierwsza w historii wizyta przywódcy komunistycznego w Stolicy Apostolskiej (Cvrlje 1980: 337-341; Pirjevec 2011: 571-572). W roku 
1977 po wejściu w życie traktatu z Osimo (1975) na miejsce Apostolskiej Administratury Słoweńskiego Przymorza Watykan powołał diecezję koperską, którą włączono w skład archidiecezji lublańskiej (Benedik 1991: 246). Pierwszym biskupem tej diecezji został jej dotychczasowy administrator Janez Jenko (Darovec 2001: 374).

\section{Epilog}

Fakt, że Paweł VI gościł w Watykanie człowieka, który miał opinię prześladowcy Kościoła katolickiego w Jugosławii, był nie lada sensacją (Tomašević 2011: 98-104). Trudno jest dzisiaj stwierdzić, czy spotkanie z papieżem wywarło wpływ na dalsze życie Tity. Według nieoficjalnej wersji, umierając w lublańskiej klinice (na początku 1980 roku), zażądał odwiedzin księdza i przyjął ostatnie sakramenty (w dzieciństwie był ministrantem). Taka wersja wydarzeń do dzisiaj krąży w środowisku słoweńskiego duchowieństwa. Epizod ten przedstawił Žarko Petan w swojej farsie Wspaniałe życie Josipa Broz Tito (Petan 2005: 72-74). Tezę tę odrzuca natomiast słoweński badacz Božo Repe, należący do nielicznych historyków, którzy mieli możliwość zapoznania się z przechowywanymi w Archiwum Słowenii materiałami dotyczącymi ostatnich dni Tity (Repe 2001: 3). Faktu spowiedzi Tity nie wyklucza Jože Pirjevec, który zgadza się z tezą, że nawet gdyby do niej doszło, to ze względu na tajność nie mogłaby być odnotowana w dokumentacji (ustna informacja uzyskana od profesora Pirjevca).

Następnego dnia po śmierci prezydenta Jugosławii, 5 maja 1980 roku, w stolicy Słowenii odbyło się oficjalne pożegnanie zmarłego. Kiedy po ulicach Lublany wśród tłumów przejeżdżała laweta z trumną Josipa Broz Tity, w mieście biły dzwony kościelne. Według niektórych interpretacji, dzwony te miały symbolizować powrót Tity na łono Kościoła katolickiego.

\section{Literatura}

Akmadža M., 2003, Uzroci prekida diplomatskih odnosa između Vatikana i Jugoslavije 1952. godine, „Croatica Christiana Periodica” nr 52, t. 27, s. 171-202. 
Akmadža M., 2004, Pregovori Svete Stolice i Jugoslavije i potpisivanje protokola iz 1966. godine, „Časopis za suvremenu povijest” nr 2, r. 36, s. 473-503.

Akmadža M., 2008, Crkva i država. Dopisivanje i razgovori između predstavnika Katoličke crkve i komunističke državne vlasti u Jugoslaviji, t. 1, Zagreb.

Bekić D., 1988, Jugoslavija u hladnom ratu. Odnosi s velikim silama 1949-1955, Zagreb.

Benedik M., (red.), 1991, Zgodovina Cerkve na Slovenskem, Celje.

Blumenwitz D., 2005, Okupacija in revolucija v Sloveniji (1941-1946), Celovec.

Ceglar L., 1993, Nadškof Vovk in njegov čas (1900-1963), t. 1, Celovec.

Ceglar L., 1997, Nadškof Vovk in njegov čas (1900-1963), t. 3, Celovec.

Ceglar L., 1998, Nadškof Vovk in njegov čas (1900-1963), t. 4, Celovec.

Cvrlje V., 1980, Vatikan u suvremenom svijetu, Zagreb.

Darovec D., (red.), 2001, 1400. letnica Koprske škofije in omembe Slovanov v Istri, „Acta Histriae” nr 9, s. 1-128.

Dolinar F., Griesser-Pečar T., 1996, Rožmanov proces, Ljubljana.

Dolinar F., 1998, Cerkvena uprava in Slovenci, w: Slovenija 1948-1998. Iskanje lastne poti, Maribor, s. 198-215.

Ferenc T., 1997, Cerkev na slovenskem pod nemško in italijansko okupacijo, w: T. Ferenc, Cerkev in družba na Goriškem ter njih odnos do vojne in osvobodilnih gibanj, Gorizia.

Griesser-Pečar T., 2004, Razdvojeni narod. Slovenija 1941-1945, Ljubljana.

Godeša B., 2004, Tisova Slovaška - «priljubljeni sen slovenskega klerofašizma»?, „Zgodovinski časopis” nr 1-2, r. LVIII, s. 69-80.

Godeša B., 2011, Čas odločitev. Katoliški tabor in začetek okupacije, Ljubljana.

Graovac I., 2000, Sudjelovanje i stradanje katoličkog svećenstva u partizanima 1941-1945 godine, w: Dijalog povjesničara/istoričara, t. 2, Zagreb, s. 537-550.

Grmič V., 1997, Zvesto pričevanje za evangelij in narod lavantinskega škofa dr. Ivana Jožefa Tomažiča, „Časopis za zgodovino in narodopisje” nr 1, s. 61-71.

Jeri J., 1961, Tržaško vprašanje po drugi svetovni vojni. Tri faze diplomatskega boja, Ljubljana.

Kacin-Wohlnz M., 1982, Fašistični programi raznarodovanja Slovencev in Hrvatov v Julijski krajini, „Prispevki za novejšo zgodovino” r. XXII, s. 151-167.

Lešnik D., Tomc G., 1995, Rdeče in črno: slovensko partizanstvo in domobranstvo, Ljubljana.

Maršal Tito, podpredsednik zvezne vlade Edvard Kardelj in predsednik narodne vlade Slovenije Boris Kidrič «O pastirskem pismu», 1945, Ljubljana.

Merlak I., 2002, Za Cerkev in narod, Ljubljana, s. 8-10.

Mlakar B., 1999, Vaške straže ter prostovoljna protikomunistična milica, w: Mati, Domovina, Bog, Ljubljana.

Otrin B., Štrukelj A., 2008, Arcybiskup Anton Vovk. Stuga Boży, przeł. M. Żerańska, M. Jagodziński, Ljubljana.

Pacek D., 2012, Pregled zgodovine Katoliške akcije na Slovenskem, „Bogoslovni vestnik" nr 2, r. 72, s. 219-234. 
Petan Ž., 2005, Čudovito življenje Josipa Broza Tita, Ljubljana.

Pirjevec J., 2011, Tito in tovariši, Ljubljana.

Prinčič J., 2013, Križ in kapital. Premoženje, financiranje in podjetniška dejavnost RKC na Slovenskem, Ljubljana.

Prisega domobranske vojske, 1944,,Slovenec”, 21 kwietnia, s. 2-3.

Rahten A., 2001, Slovenska ljudska stranka v dunajskem parlamentu: slovenska parlamentarna politika v habsburški monarhiji 1897-1914, Celje.

Repe B., 2001, Slovenci v osemdesetih letih, Ljubljana.

Repe B., 2003, Rdeča Slovenija. Tokovi in obrazi socializma, Ljubljana.

Režek M., 1999, „, Vprašanje svobode vere je vprašanje osvoboditve cerkve od Vatikana”, Odnosi med državo in katoliško cerkvijo v letih 1949-1953, „Zgodovinski časopis" nr 3, r. LIII, s. 367-389.

Režek M., 2004, Jugoslavija, Vatikan in katoliška cerkev (1949-1953), w: Jugoslavija v hladni vojni, Ljubljana, s. 375-387.

Rožman G., 1941, Pomembni zgodovinski dogodki, „Ljubljanski škofijski list” 31 lipca, s. 1 .

Rožman G., 1943, Pastirskega pisma o nevarnosti brezbožnega komunizma, „Ljubljanski škofijski list", 30 listopada, s. 89-96.

R.K., 1965, Katoliška cerkev v Jugoslaviji, „Zbornik. Svobodna Slovenija”, s. 73-83.

Škulj E. (red.), 2001, Rožmanov simpozij v Rimu, Celje.

Stehle H., 1993, Tajna dyplomacja Watykanu. Papiestwo wobec komunizmu (1917-1991), Warszawa.

Tomašević S., 2011, Tito u Vatikanu. Stepinčev progonitelj kod pape Pavla VI, Zagreb.

Włodarczyk T., 1986, Konkordaty. Zarys historii ze szczególnym uwzględnieniem XX wieku, t. 2, Warszawa.

Vovk A., 2003, V spomin in opomin. Osebni zapiski škofa Antona Vovka od 1945 do 1953, Ljubljana. 